\title{
Emerging Markets for GM Foods: \\ An Indian Perspective on Consumer Understanding and Willingness to Pay
}

\author{
Satish Y. Deodhar \\ Sankar Ganesh \\ Wen S. Chern
}

W.P. No.2007-06-08

June 2007

The main objective of the working paper series of the IIMA is to help faculty members, research staff and doctoral students to speedily share their research findings with professional colleagues and test their research findings at the pre-publication stage. IIMA is committed to maintain academic freedom. The opinion(s), view(s) and conclusion(s) expressed in the working paper are those of the authors and not that of IIMA.

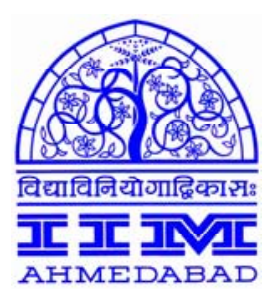

\section{INDIAN INSTITUTE OF MANAGEMENT \\ AHMEDABAD-380 015 \\ INDIA}




\title{
Emerging Markets for GM Foods: \\ An Indian Perspective on Consumer Understanding and \\ Willingness to Pay*
}

\begin{abstract}
This paper addresses the issues of consumer awareness, opinion, acceptance and willingness to pay for GM foods in the Indian market. A random utility approach is used to estimate a logit equation which indicates what factors affect the likelihood of consumption of non-GM and GM foods and whether or not consumers are willing to pay a premium for non-GM/GM foods. Data was generated through a questionnaire survey which was administered to 602 respondents in the city of Ahmedabad and 110 respondents on internet. More than $90 \%$ of the respondents from the city survey did not know about GM foods. However, after informing them about the pros and cons of GM foods, more than 70\% were willing to consume even if GM and non-GM foods were available for the same price. Ceteris paribus as the price difference between non-GM and GM food rose, people were more likely to consume GM foods. Likelihood of GM food consumption seemed to increase as one moved away from the very poor income bracket to middle income brackets. However, moving to the high income bracket does not seem to increase this likelihood. Being a female or a joint family member increased the likelihood of choosing non-GM rice and edible oil. On an average, consumers were willing to pay $19.5 \%$ and $16.12 \%$ premiums for golden rice and GM edible oil, respectively. In case of chicken, consumers seemed to pay a very negligible premium for non-GM fed chicken. Overall, it appears that GM foods may be acceptable in the Indian market. However, consumer education societies, government ministries, and biotech food crop companies may have to create awareness about the GM foods among Indian consumers.
\end{abstract}

\footnotetext{
* Generous support for the study extended by Centre for Management in Agriculture, Indian Institute of Management, Ahmedabad is acknowledged. We appreciate the input given by Dr. Naoya Kaneko, Post-Doctoral Associate, University of Georgia. Authors would also like to thank Dr. D.S. Parmar for translating English version of the survey questionnaire into Gujarati and Mr. Prahlad Patni for typing the Gujarati version in MS Word.
} 


\section{Emerging Markets for GM Foods: \\ An Indian Perspective on Consumer Understanding and \\ Willingness to Pay}

\section{Background and Motivation}

India has been a late entrant in introducing GM crops for commercial use. While China and US had introduced GM crops by the middle of the last decade, India allowed commercial production of its first GM crop, Bt Cotton, only in 2002. However, since then, India made a rapid progress in the production of GM cotton. With an area of about 10 million acres under Bt cotton in 2006, India has surpassed the early entrant, China to become the $5^{\text {th }}$ largest country in terms of area under GM crops (ISAAA, 2007). However, no permission has been given so far for the commercial production of food crops. Interestingly, in many states of India, particularly in the cotton producing states such as Gujarat, cottonseed oil is commonly used as a cooking medium. Therefore, inadvertently GM edible oil might have already made its way into the market. Moreover, various GM food crops are in their laboratory and field trial stages of development, both in private sector and public research institutions (USDA, 2005).

While food technologists have worked on the GM technology per se, economists have also contributed to the related supply-side issues. For example, in the Indian context, pros and cons of GM technology and the grower violations of patent rights have been studied by Gupta and Chandak (2005). A study by Neilsen and Anderson (2000) indicated that if insect resistant $\left(1^{\text {st }}\right.$ generation) GM rice varieties were to be introduced internationally, then India would stand to benefit to the tune of $\$ 1178$ million and benefit to the world economy would be of $\$ 6.2$ billion in 1995 dollars. The studies and researches mentioned above have focused on the technology and supply side issues. The demand side of the Indian market has been ignored altogether. In our understanding, no study has been conducted in India that tries to understand the GM crop issue from consumers' perspective. For example, Neilsen and Anderson study made a strong assumption that the consumers were indifferent between GM and non-GM crops. At the same time, however, they did exclude EU and Japan from their model because of restrictions on GM crops in those countries. 
With rapid development of GM food crops in India and around the world, liberalized trade environment, stagnant productivity of green-revolution-era crops, and the burgeoning of population; policy makers would very soon be asking themselves - When (and not If) they should allow production and import of GM food crops. In fact, India has now eliminated customs duty on import of corn due to the pressure from the poultry sector and the starch manufacturing industry (Grainnet, 2007). And, most likely India would receive such imports from countries that produce GM corn. Unfortunately, at this time, neither the exporters have explicit GM/non-GM labelling requirement put in place nor India has an effectively operational GM testing mechanism in place. While one may argue that consumers may be less concerned whether or not their cotton clothes are made up of GM cotton or non-GM cotton (non-food crop), the same, however, may not be assumed regarding food (crops).

What is the level of awareness among Indian consumers regarding GM foods? What are their perceptions and attitudes towards consumption of GM foods? What is their willingness to pay for GM foods? These questions need to be addressed first if GM foods are to be introduced in India in the near future. In developed countries the debate about GM foods among various stakeholders has been going on for quite sometime now. Studies have also been conducted in many countries including Argentina, Australia, China, and Italy that try to understand consumers' awareness, acceptance, and willingness to pay for GM foods (e.g., Kaneko and Chern, 2005; Zhong et al., 2002). This study is an attempt to investigate consumers' understanding, perception and willingness to pay for GM foods in India.

In this context we conducted a consumer survey - through household visits in the city of Ahmedabad, India and through a web portal eliciting e-mail responses regarding consumers' understanding, perception, acceptance and willingness to pay for GM foods. The survey also elicited information on consumers' demographics, income, attitudes, and other preferences. We realize that households from rural towns across India on one hand, and households from the modern mega-cities like Mumbai and Delhi on the other are quite different from each other. Hence, their responses to our questionnaire may vary quite a lot. Ours being the first study of this kind in India, we selected the city of 
Ahmedabad, Gujarat which represented a mix of rural town and urban city dwelling households. Apart from this, we also conducted an internet based survey.

\section{Questionnaire, Survey, and Choice of Food Products}

\section{The Questionnaire and Survey}

For the survey we developed a questionnaire adapted from the work of Kaneko and Chern (2005). Initially, the questionnaire provided a brief introduction to what GM foods are, as also the benefits and concerns regarding the technology in a language a layperson can understand. For ease of understanding of the questionnaire by the households, the text was also translated into Gujarati, the state language of Gujarat. The questionnaire consisted of seven sections. The first three sections sought to gather information on respondents' food purchasing habits, knowledge, attitude, and perception with regard to GM (food) technology, and their views on GM food regulation. The next three sections we covered a series of questions on three food items which form part of household consumption in Gujarat, and which have a potential for commercial introduction of GM varieties. The last section was concerned with socioeconomic and demographic information.

The surveys were conducted during the months of February, March and April 2006 in Ahmedabad city. The pilot questionnaire was tested by administering it to 10 households. Field investigators from a reputed agency were hired for the household interviews. They were given training on the specifics of the questionnaire and the pilot interviews were personally monitored. Ahmedabad Municipal Corporation (AMC) has divided the city into 43 wards. From each of these wards, 12 to 15 households were randomly selected for administering the questionnaire. A total of 602 filled and usable questionnaires were considered for the analysis. Different groups of wards among the 43 wards represented a continuum on the socio-economic ladder of the society. A web based survey was also developed for the same questionnaire, where various stakeholders including businesspersons, scientists and students were asked to fill-out the questionnaire online. Sample size of the returned usable internet based questionnaires was 110 .

\section{The Choice of Food Products}

We selected vegetable oil (cottonseed oil), rice and a non-vegetarian product (chicken) for our analysis. We chose these products because GM varieties of such food products 
have either already appeared in foreign markets, they have a potential for introduction in India, and/or they might have appeared in the food chain in India in some form or the other. GM soybeans are quite common in US, and, hence, so are GM based edible vegetable oils. In India, cultivation of Bt cotton has been a success story in the state of Gujarat. At the same time, edible cottonseed oil has been a popular cooking medium in Gujarat. Therefore, we chose edible (GM) oil with particular reference to cottonseed oil as one of our products under consideration. Although no GM related foods are allowed in India at this time, cottonseed oil pressed out of Bt cottonseeds probably has made an inadvertent entry onto the consumer plate.

In the case of rice, we chose to make a comparison between the conventional rice and the GM rice which is popularly known as golden rice. Golden rice is a genetically modified rice crop capable of producing provitamin-A (beta-carotene) which is not present in traditional rice varieties. This rice has a vast potential as a source of alleviation of vitamin A (retinol) deficiency in the diets of poor and disadvantaged people in developing countries. According to the World Health Organization (WHO), vitamin A deficiency (VAD) is the leading cause of preventable blindness in children. It is estimated that 250,000 to 500,000 children with VAD become blind every year and half of those children die within a year of losing their sight. Nearly 600,000 women die from childbirth-related causes each year, many of them from complications which could be reduced through better provision of vitamin A (Sommer and West, 1996). India figures prominently in such reported deficiencies. In this context, Golden Rice Humanitarian Board, along with its partner institutions in India has been entrusted with evaluating the need for golden rice, analyzing and comparing pros and cons of it, and setting a framework for implementation of a golden rice that best suits the needs in India.

Finally, we have considered one of the meat products, chicken in our analysis. This choice was an obvious one, for among the non-vegetarians in India, consumption of chicken is quite significant. Among other meat products, beef and ham are religious taboo, and mutton is very expensive. It is quite possible that eventually chickens will be given feed that is made of GM corn or other GM oilseed meal. In fact, unknowingly this might be happening at this time. One does not know if informed consumers would like to eat chicken that is fed with GM feed. 


\section{Analytical Framework}

Following Kaneko and Chern (2005), we use the random utility approach of making a dichotomous choice between GM and non-GM foods. Let consumer j's indirect utility function from choosing alternative $i$ be given by:

$$
\mathrm{U}_{\mathrm{ij}}=\mathrm{u}\left(\mathrm{D}_{\mathrm{j}}, \mathrm{Z}_{\mathrm{j}}, \mathrm{g}_{\mathrm{ij}}\right)
$$

where $D_{j}$ is the income variable, $Z_{j}$ is a vector of variables representing respondent characteristics that influence utility, and $\mathrm{g}_{\mathrm{ij}}$ is the random component that represents factors unknown to the researcher. Consumer $j$ chooses alternative $i$ if $U_{i j}>U_{k j}$ for all $\mathrm{k} \neq \mathrm{i}$. We assume that:

$$
\mathrm{U}_{\mathrm{ij}}=\mathrm{V}_{\mathrm{ij}}+\mathrm{g}_{\mathrm{ij}} \text {, }
$$

where $\mathrm{V}_{\mathrm{ij}}$ is the deterministic component of the utility. Further, the deterministic component is considered to be a linear function. If there are two alternatives, namely consuming GM food $(i=0)$ or non-GM food $(i=1)$, then the deterministic component is given by:

$$
\mathrm{V}_{0 \mathrm{j}}=\mathrm{a}_{0}+\mathrm{b}_{0} \mathrm{Z}_{\mathrm{j}}+\mathrm{c}_{0}\left(\mathrm{D}_{\mathrm{j}}-\mathrm{Pgm}_{\mathrm{j}}\right) \text {, and }
$$

$$
V_{1 j}=a_{1}+b_{1} Z_{j}+c_{1}\left(D_{j}-P n_{j}\right),
$$

where $\operatorname{Pgm}_{\mathrm{j}}$ and $\mathrm{Pngm}_{\mathrm{j}}$ are the prices faced by consumer $\mathrm{j}$ for GM and non-GM food item. Finally, we define a latent variable $\mathrm{I}^{*}$ as:

$$
I^{*}=\left(U_{1 j}-U_{0 j}\right)=a_{1}+b_{1} Z_{j}+c_{1}\left(D_{j}-P n g m_{j}\right)+g_{1 j}-a_{0}-b_{0} Z_{j}-c_{0}\left(D_{j}-P g m_{j}\right)-g_{0 j}
$$

Assuming that marginal utility of money is constant $\left(\mathrm{c}_{1}=\mathrm{c}_{0}\right)=\mathrm{c}$, and letting $\left(\mathrm{a}_{1}-\mathrm{a}_{0}\right)=\mathrm{a}$, $\left(b_{1}-b_{0}\right)=b,\left(g_{1 j}-g_{0 j}\right)=g_{j}$, equation (5) can be re-written as:

$$
I^{*}=a+b Z_{j}-c\left(\operatorname{Pngm}_{j}-\operatorname{Pgm}_{j}\right)+g_{j} \text {, or }
$$

$$
I^{*}=a+b Z_{j}-c \Delta P+g_{j}
$$


where $\Delta \mathrm{P}=\left(\mathrm{Pngm}_{\mathrm{j}}-\mathrm{Pgm}_{\mathrm{j}}\right)$. Respondent $\mathrm{j}$ chooses non-GM food $(\mathrm{i}=1)$ if $\mathrm{I}^{*}>0$ and GM $(\mathrm{i}=0)$ if $\mathrm{I}^{*} \leq 0$. Latent variable $\mathrm{I}^{*}$ ranges from $-\infty$ to $+\infty$. We convert the equation into a probabilistic functional form by considering the following representation which converts the dependent variable range between 0 and 1 :

$$
\operatorname{Prob}\left(\text { Non-Gm) }=\mathrm{E}\left(\mathrm{i}=1 \mid \mathrm{Z}_{\mathrm{j}}, \Delta \mathrm{P}\right)=\left[1+\mathrm{e}^{-\mathrm{Xj}}\right]^{-1},\right.
$$

where, $\mathrm{X}_{\mathrm{j}}=\mathrm{a}+\mathrm{bZ} \mathrm{j}_{\mathrm{j}}-\mathrm{c} \Delta \mathrm{P}$. Converting equation (8) into a log odds ratio, we econometrically estimate it using logit.

The contingent valuation (CV) questions from the survey questionnaire make respondents choose between a current alternative and a proposed alternative at different prices. The difference in payment, therefore, gives respondent's wiliness to pay (WTP) in order to achieve the proposed scenario. WTP is arrived at by finding the proposed price of nonGM product that would make the respondent indifferent between consuming GM food and non-GM food. Therefore, WTP for non-GM product can be defined as:

$$
a_{1}+b_{1} Z_{j}+c\left(D_{j}-\text { WTPngm }_{j}\right)+g_{1 j}=a_{0}+b_{0} Z_{j}+c\left(D_{j}-W_{T P g m}^{j}\right)+g_{0 j}
$$

Solving (9) we get:

$$
\begin{aligned}
& \text { WTPngm }_{j}-\text { WTPgm }_{j}=\left[a+b Z j+g_{j}\right] / c \text {, and } \\
& \text { E } \left._{\text {WTPngm }}-\text { WTPgm }_{j}\right]=a / c+b / c \bar{Z}_{j}
\end{aligned}
$$

The expected WTP can be calculated by solving equation (11).

In the description of the model above, we referred to Contingent valuation (CV) technique being used in the questionnaire. $\mathrm{CV}$ is a survey-based economic technique for the valuation of non-market resources. While these resources may give people utility, they do not have a price as they are not sold in the market. The approach asks people to directly report their willingness to pay (WTP) to obtain a specified good, or willingness to accept (WTA) to give up a good. We used this technique in eliciting consumer willingness to pay for GM foods, precisely for the reason that while we consider actual 
market prices of non-GM food products, we use hypothetical (but realistic enough) prices of GM foods which we allow to vary around the actual market prices of non-GM foods.

The CV part of the questionnaire consisted of sequential closed-ended binary choice questions. To calculate WTP we use a stated choice method (SCM), which is based upon buyers' hypothetical choice for GM food purchases. The choice experiment consisted of five steps and except for the first step other steps consisted of one binary choice for each product. In the first step, the respondents were asked if they would choose non-GM food, GM food, or would they be indifferent given identical prices for non-GM vegetable oil and GM vegetable oil, non-GM rice and golden rice, and, non-GM fed chicken and GM fed chicken. Based on the respondents' choice, they were asked up to four follow-up questions by offering price reductions of ten percent at every step to a maximum of forty percent for the commodity they did not choose. If the respondent switched alternatives, the questioning stops. Else another question follows until the final one. The base prices chosen reflected prices for the non-GM products in stores in Ahmedabad during March 2006. The indifferent respondents in step one were randomly offered reduced price for one of the alternatives and their choice was elicited. Finally, the choices made in each step are taken as separate observations in the econometric analysis.

\section{Descriptive Statistics and Regression Results}

\section{$\underline{\text { Socio-economic Characteristics }}$}

As mentioned earlier, we collected data both through one-on-one interviews in the city of Ahmedabad as well as the web based survey. We have a data on 602 respondents from the city survey and 110 respondents from internet based survey. The economic status of the survey samples is presented in Table 4.1(a). The modal value of city respondents (44.48\%) and internet based respondents (34\%) is in the income brackets of Rs. 50,000 to 100,000 and Rs. 250,000 to 500,000 respectively. Clearly, internet based respondents have a better economic status. The socio-demographic data of the sample is provided in Table 4.1(b). In the city based survey, about $65 \%$ of the respondents are females. The average age of the respondents is 37 years with a standard deviation of 10 years, and $73 \%$ of all respondents have children under the age of 18 years. $63 \%$ have done their schooling and 34 percent have completed their (bachelors) graduation. Nearly 76 percent live in a joint family. In comparison, for the internet survey, majority of the respondents 
(99\%) are either graduates or post-graduates. About $74 \%$ of the respondents are students, $79 \%$ are male, $86 \%$ with a nuclear family, and about $64 \%$ do not have any children.

Table 4.1(a): Income Distribution of the Respondents

\begin{tabular}{|c|c|c|c|c|}
\hline \multirow[t]{2}{*}{ Particulars } & \multicolumn{2}{|c|}{ City Survey } & \multicolumn{2}{|c|}{ Internet Survey } \\
\hline & Number & Percentage & Number & Percentage \\
\hline \multicolumn{5}{|c|}{ Yearly total household income ( Rs) } \\
\hline$<50000$ & 147 & 24.58 & 4 & 3.64 \\
\hline 50000 to $<1$ lakh & 266 & 44.48 & 9 & 8.18 \\
\hline 1 lakh to $<2.5$ lakhs & 149 & 24.92 & 31 & 28.18 \\
\hline 2.5 lakhs to $<5$ lakhs & 33 & 5.52 & 37 & 33.64 \\
\hline 5 lakhs to $<10$ lakhs & 3 & 0.50 & 20 & 18.18 \\
\hline$\geq 10$ lakhs & & & 9 & 8.18 \\
\hline Total & $598^{*}$ & 100 & 110 & 100 \\
\hline
\end{tabular}

* 4 respondents did not reveal their income

Table 4.1(b): Socio-Demographic Characteristics of the Respondents

\begin{tabular}{|c|c|c|c|c|}
\hline \multirow[t]{2}{*}{ Particulars } & \multicolumn{2}{|c|}{ City survey } & \multicolumn{2}{|c|}{ Internet Survey } \\
\hline & Number & Percentage & Number & Percentage \\
\hline \multicolumn{5}{|l|}{ 1. Gender } \\
\hline Female & 390 & 64.78 & 23 & 20.91 \\
\hline Male & 212 & 35.22 & 87 & 79.09 \\
\hline \multicolumn{5}{|c|}{ 2. Marital status } \\
\hline Married & 548 & 91.03 & 31 & 28.18 \\
\hline Unmarried & 52 & 8.64 & 77 & 70.00 \\
\hline Others & 2 & 0.33 & 2 & 1.82 \\
\hline \multicolumn{5}{|c|}{ 3. Working status } \\
\hline Employed & 156 & 25.91 & 29 & 26.36 \\
\hline Students & 10 & 1.66 & 81 & 73.64 \\
\hline Homemakers & 329 & 54.65 & & \\
\hline Retired & 19 & 3.16 & & \\
\hline Unemployed & 5 & 0.83 & & \\
\hline Others & 83 & 13.79 & & \\
\hline \multicolumn{5}{|l|}{ 4. Education } \\
\hline Illiterate & 21 & 3.49 & & \\
\hline High School & 377 & 62.63 & 1 & 0.91 \\
\hline College & 204 & 33.89 & 99 & 99.09 \\
\hline \multicolumn{5}{|c|}{ 5. Family Type } \\
\hline Nuclear & 146 & 24.25 & 98 & 86.09 \\
\hline Joint & 456 & 75.75 & 12 & 10.91 \\
\hline \multicolumn{5}{|l|}{ 6. Children } \\
\hline No Children & 160 & 26.58 & 70 & 63.64 \\
\hline Have children & 442 & 73.42 & 40 & 26.36 \\
\hline \multicolumn{5}{|l|}{ 7. Age } \\
\hline Mean Years & 37 & 10 (std dev) & 29 & $10($ std dev $)$ \\
\hline
\end{tabular}




\section{Consumer Awareness and Opinion}

In March 2002, India's Genetic Engineering Approval Committee (GEAC) had granted permission for the commercial cultivation of a GM cotton crop (Bt Cotton) resistant to bollwarm. Although success of the crop in different states of India was mixed, the crop was very successful in the state of Gujarat. It is also true that cottonseed oil is one of the popular cooking mediums in Gujarat. The city of Ahmedabad being in the same state, we thought of assessing awareness among the consumers regarding GM crops. We asked two questions to the respondents - one on the knowledge about GM foods and organisms and other on the awareness about the GM cotton. As reported in Table 4.2, an overwhelming proportion of respondents in Ahmedabad were unaware of GM foods and organisms and GM cotton. In the case of web based survey, however, relatively small proportion of respondents had no idea about GM foods, organisms and GM cotton.

Table 4.2: Consumer Awareness about GM Technology

\begin{tabular}{|l|r|r|r|r|}
\hline \multirow{2}{*}{ Particulars } & \multicolumn{2}{|c|}{ City Survey } & \multicolumn{2}{c|}{ Internet Survey } \\
\cline { 2 - 5 } & Number & Percentage & Number & Percentage \\
\hline 1. Before this survey, how well did you know about GM foods or GM organisms \\
\hline Very well & 9 & 1.49 & 25 & 22.73 \\
\hline Somewhat & 61 & 10.13 & 70 & 63.64 \\
\hline Not at all & 532 & \multicolumn{3}{|c|}{15} \\
\hline 2.The GM technology has been used to create cotton that is resistant to pest \\
\hline Agree & 38 & 6.31 & 78 & 70.90 \\
\hline Disagree & 10 & 1.66 & 6 & 5.45 \\
\hline Don't know & 554 & 92.03 & 26 & 23.63 \\
\hline
\end{tabular}

We tried to understand consumer opinions through the attitudes and perceptions regarding various aspects related to GM foods. This included their views on health risk, religious and ethical concerns, and their views on government regulations and labelling. Before eliciting their responses, we briefly informed them about what the GM technology is about, and what are the main benefits and concerns. The results given below reveal that about $70 \%$ of the city respondents are inclined to believe that GM foods are safe (Table 4.3). On the other hand, about $60 \%$ of the internet based respondents seem to be either indifferent or consider GM foods somewhat risky. With respect to ethical and religious concerns, more that half of the city respondents consider them to be important, whereas for web based respondents these percentages are $27 \%$ and $20 \%$ respectively. 
Table 4.3: Consumer Perceptions of GM Food

\begin{tabular}{|c|c|c|c|c|}
\hline \multirow[t]{2}{*}{ Particulars } & \multicolumn{2}{|c|}{ City Survey } & \multicolumn{2}{|c|}{ Internet Survey } \\
\hline & Number & Percentage & Number & Percentage \\
\hline \multicolumn{5}{|c|}{$\begin{array}{l}\text { 1. Between GM and Non-GM foods, how would you rate GM foods in terms of their } \\
\text { effects on human health }\end{array}$} \\
\hline Extremely risky & 7 & 1.16 & 1 & 0.91 \\
\hline Somewhat risky & 48 & 7.97 & 37 & 33.64 \\
\hline Indifferent & 87 & 14.45 & 29 & 26.36 \\
\hline Somewhat safe & 184 & 30.56 & 11 & 10.00 \\
\hline Extremely safe & 241 & 40.03 & 2 & 1.82 \\
\hline Don't know & 35 & 5.81 & 30 & 27.27 \\
\hline \multicolumn{5}{|c|}{ 2. Importance of ethical concerns in consuming GM foods } \\
\hline Extremely important & 110 & 18.27 & 11 & 10.00 \\
\hline Somewhat important & 201 & 33.39 & 19 & 17.27 \\
\hline Indifferent & 69 & 11.46 & 29 & 26.36 \\
\hline Somewhat unimportant & 21 & 3.49 & 15 & 13.64 \\
\hline Extremely unimportant & 197 & 32.72 & 36 & 32.73 \\
\hline Don't know & 4 & 0.66 & 0 & 0 \\
\hline \multicolumn{5}{|c|}{ 3. Importance of religious concerns in consuming GM foods } \\
\hline Extremely important & 175 & 29.07 & 5 & 4.55 \\
\hline Somewhat important & 146 & 24.25 & 17 & 15.45 \\
\hline Indifferent & 53 & 8.80 & 24 & 21.82 \\
\hline Somewhat unimportant & 30 & 4.98 & 10 & 9.09 \\
\hline Extremely unimportant & 195 & 32.39 & 54 & 49.09 \\
\hline Don't know & 3 & 0.50 & 0 & 0 \\
\hline
\end{tabular}

Table 4.4: Consumer Opinion on Labelling of GM foods

\begin{tabular}{|l|r|r|r|r|}
\hline \multirow{2}{*}{ Particulars } & \multicolumn{2}{|c|}{ City Survey } & \multicolumn{2}{c|}{ Internet Survey } \\
\cline { 2 - 5 } & Number & Percentage & \multicolumn{1}{l|}{ Number } & Percentage \\
\hline 1. How important it is to label food products for GM/non-GM attributes \\
\hline Extremely important & 514 & 85.38 & 85 & 77.27 \\
\hline Somewhat important & 71 & 11.79 & 19 & 17.27 \\
\hline Indifferent & 8 & 1.33 & 4 & 3.64 \\
\hline Somewhat unimportant & 3 & 0.50 & 2 & 1.82 \\
\hline Extremely unimportant & 4 & 0.66 & & \\
\hline Don't know & 2 & 0.33 & & \\
\hline 2. Preferred type of labelling & \multicolumn{5}{|l|}{} \\
\hline Mandatory Labelling & 562 & 93.36 & 105 & 95.45 \\
\hline Voluntary Labelling & 24 & 3.99 & 5 & 4.55 \\
\hline No Labelling is Necessary & 12 & 1.99 & & \\
\hline Don't know & 4 & 0.66 & & \\
\hline
\end{tabular}

Further, we sought respondent opinion on labelling issue. We asked, "How important it is to label food products for GM/Non-GM attributes?" More than $85 \%$ of respondents from city survey and more than $77 \%$ of respondents from internet survey opined that 
labelling is extremely important (Table 4.4). Importantly, more than $93 \%$ of respondents in both surveys prefer mandatory labelling over voluntary labelling. However, when it comes to paying extra amount for labelling, about $28 \%$ of respondents from city survey are against it. More than 35 percent of the consumer support labelling if the prices are raised by not more than by 5 percent. In the internet survey, only about $5 \%$ of respondents are not willing to pay anything extra as labelling cost. In fact, about $34 \%$ are ready to pay more than $15 \%$ of price as labelling cost (Table 4.5 ).

Table 4.5: Willingness-to-Pay Extra for Labelling

\begin{tabular}{|l|r|r|r|r|}
\hline \multirow{2}{*}{ Particulars } & \multicolumn{2}{|c|}{ City Survey } & \multicolumn{2}{|c|}{ Internet Survey } \\
\cline { 2 - 5 } & Number & \multicolumn{1}{|c|}{ Percentage } & Number & Percentage \\
\hline $\begin{array}{l}\text { Don't support labelling if the food } \\
\text { price increases }\end{array}$ & 167 & 27.74 & 5 & 4.55 \\
\hline $\begin{array}{l}\text { Support labelling only if the prices } \\
\text { are higher by no more than five } \\
\text { percent }\end{array}$ & 216 & 35.88 & 46 & 41.82 \\
\hline $\begin{array}{l}\text { Support labelling even if the prices } \\
\text { are higher than 5\% but no more than } \\
10 \% \text { percent }\end{array}$ & 105 & 17.44 & 19 & 17.27 \\
\hline $\begin{array}{l}\text { Support labelling even if the prices } \\
\text { are higher than 10\% but no more } \\
\text { than 15\% percent }\end{array}$ & 31 & 5.15 & 2 & 1.82 \\
\hline $\begin{array}{l}\text { Support labelling even if the prices } \\
\text { are higher than 15\% }\end{array}$ & 67 & 11.13 & 37 & 33.64 \\
\hline
\end{tabular}

\section{Acceptance and Willingness to Pay}

Although, currently GM foods are not available in Indian markets, there is a distinct possibility of these foods entering the Indian market. Hence attempt was made to study consumers' acceptance of GM foods in general and their willingness to buy GM food which have attributes such as crop resistance to pests and enriched vitamin contents. Results in Table 4.6 show that a majority of the city survey respondents (72\%) and about $28 \%$ of the web based survey respondents claimed that they were somewhat or extremely willing to consume foods produced with GM ingredients. Reduction in pesticide use was considered quite favourably by respondents in both the city survey and internet survey. About $85 \%$ and $77 \%$ of respondents respectively were somewhat or extremely willing to consume GM foods if pesticide use gets reduced. The response was very similar if GM foods were to have more nutrition than conventional foods. In contrast, if GM foods 
posed a risk of allergic reactions, the acceptance for GM foods was low. The acceptance levels were very low for internet based respondents. While only $44 \%$ of city respondents were somewhat or extremely unwilling to consume GM foods, this percentage was very high at $87 \%$ for the internet based respondents.

Table 4.6: Consumer Acceptance of GM Foods

\begin{tabular}{|l|r|r|r|r|}
\hline \multirow{2}{*}{ Particulars } & \multicolumn{2}{|c|}{ City survey } & \multicolumn{2}{c|}{ Internet based survey } \\
\cline { 2 - 5 } & Number & Percentage & Number & Percentage \\
\hline \multicolumn{5}{|c|}{} \\
1. How willing are you to consume foods produced with GM ingredients \\
\hline Extremely willing & 215 & 35.71 & 7 & 6.36 \\
\hline Somewhat willing & 220 & 36.54 & 24 & 21.82 \\
\hline Neutral & 95 & 15.78 & 39 & 35.45 \\
\hline Somewhat unwilling & 27 & 4.49 & 24 & 21.82 \\
\hline Extremely unwilling & 30 & 4.98 & 9 & 8.18 \\
\hline Don't know & 15 & 2.49 & 7 & 6.36 \\
\hline
\end{tabular}

2. How willing are you to consume GM food if it reduced the amount of pesticide applied to crops

\begin{tabular}{|l|r|r|r|r|}
\hline Extremely willing & 390 & 64.78 & 46 & 41.82 \\
\hline Somewhat willing & 125 & 20.76 & 39 & 35.45 \\
\hline Neutral & 48 & 7.97 & 13 & 11.82 \\
\hline Somewhat unwilling & 21 & 3.49 & 6 & 5.45 \\
\hline Extremely unwilling & 12 & 1.99 & 3 & 2.73 \\
\hline Don't know & 6 & 1.00 & 3 & 2.73 \\
\hline
\end{tabular}

3. How willing are you to consume GM food if it posed a risk of causing allergic reactions for some people

\begin{tabular}{|l|r|r|r|r|}
\hline Extremely willing & 52 & 8.64 & 0 & 0 \\
\hline Somewhat willing & 107 & 17.77 & 6 & 5.45 \\
\hline Neutral & 152 & 25.25 & 4 & 3.64 \\
\hline Somewhat unwilling & 94 & 15.61 & 33 & 30.00 \\
\hline Extremely unwilling & 171 & 28.41 & 63 & 57.27 \\
\hline Don't know & 26 & 4.32 & 4 & 3.64 \\
\hline
\end{tabular}

4. How willing are you to consume GM food if it was more nutritious than similar food that isn't genetically modified

\begin{tabular}{|l|r|r|r|r|}
\hline Extremely willing & 369 & 61.30 & 31 & 28.18 \\
\hline Somewhat willing & 147 & 24.42 & 53 & 48.18 \\
\hline Neutral & 47 & 7.81 & 11 & 10.00 \\
\hline Somewhat unwilling & 23 & 3.82 & 6 & 5.45 \\
\hline Extremely unwilling & 12 & 1.99 & 5 & 4.55 \\
\hline Don't know & 4 & 0.66 & 4 & 3.64 \\
\hline
\end{tabular}

Given the level of awareness, perceptions and willingness to consume, one would like to know how much more or less consumers are willing to pay for GM foods. Would 
consumers be ready to pay a premium for non-GM foods or is it vice-versa? As described earlier, since no actual GM foods are in the market yet, we selected three (GM) foods that have a potential for adoption, namely GM rice, GM edible oil and GM fed chicken. CV technique was applied in the questionnaire to elicit consumer response based on actual market prices of the three goods and hypothetical prices of their GM variants. For example, the initial choice of the respondents between GM and non-GM foods for identical prices for both the variants is shown in Tables 4.7 and 4.8. In case of city survey a substantial proportion of respondents chose GM foods. As against this, the proportion of internet respondents who chose GM foods is very low. The proportion of indifferent respondents was extremely low in city survey, while that in internet survey was as high as $31 \%$ and $45 \%$ for edible oil and chicken respectively.

Table 4.7: Initial Choice at Equal Prices in City Survey

\begin{tabular}{|l|r|r|r|r|r|r|}
\hline \multirow{2}{*}{ Particulars } & \multicolumn{2}{|c|}{ Rice (N=602) } & \multicolumn{2}{c|}{ Edible oil(N=602) } & \multicolumn{2}{c|}{ Chicken(N=121) } \\
\cline { 2 - 7 } & Number & Percentage & Number & Percentage & Number & Percentage \\
\hline Non GM & 162 & 26.91 & 169 & 28.07 & 42 & 34.71 \\
\hline GM & 428 & 71.09 & 423 & 70.26 & 75 & 61.98 \\
\hline Indifferent & 12 & 1.99 & 13 & 1.99 & 4 & 3.30 \\
\hline
\end{tabular}

Table 4.8 Initial Choice at Equal Prices in Internet Survey

\begin{tabular}{|l|r|r|r|r|r|r|}
\hline \multirow{2}{*}{ Particulars } & \multicolumn{2}{|c|}{ Rice (N=110) } & \multicolumn{2}{c|}{ Edible oil (N=110) } & \multicolumn{2}{c|}{ Chicken (N=58) } \\
\cline { 2 - 7 } & Number & Percentage & Number & Percentage & Number & Percentage \\
\hline Non GM & 44 & 40.00 & 55 & 50.00 & 25 & 43.10 \\
\hline GM & 41 & 37.27 & 21 & 19.09 & 7 & 12.06 \\
\hline Indifferent & 25 & 22.72 & 34 & 30.90 & 26 & 44.82 \\
\hline
\end{tabular}

Subsequent to the initial choice, the questionnaire offered the respondents reduced prices from $10 \%$ to $40 \%$ on price of the alternate choice and once again they were asked to choose between GM and non-GM variety. For those who were indifferent, we reduced price of one of the variants randomly and asked respondents to make a choice between the two variants. Through this process we could elicit the price differences at which respondents switched between the variants. Having done this, we estimated binary logit models to understand what explanatory factors are critical in explaining the likelihood of consumers choosing GM or non-GM foods. Moreover, we used the estimated equations for calculating the mean willingness to pay for non-GM/GM foods. Both Survey data 
were merged and identified with a dummy variable. The list of variables and the maximum likelihood logit estimates of the model are presented in Table 4.9 and 4.10.

Table4.9: Description of Variables

\begin{tabular}{|c|l|}
\hline Variable Name & \multicolumn{1}{c|}{ Description } \\
\hline PRICE & Price difference between Non GM and GM alternatives \\
\hline KNOW & $\begin{array}{l}1 \text { if very well/somewhat informed about GMOs or GM foods; } 0 \\
\text { otherwise. }\end{array}$ \\
\hline GOVT & $\begin{array}{l}1 \text { if the government's regulatory performance is excellent or } \\
\text { good; } 0 \text { otherwise. }\end{array}$ \\
\hline HR & $\begin{array}{l}1 \text { if one thinks GM food is extremely or somewhat risky to } \\
\text { human health; } 0 \text { otherwise. }\end{array}$ \\
\hline ETHIC & $\begin{array}{l}1 \text { if one considers ethical issue is extremely or somewhat } \\
\text { important in choosing food product; } 0 \text { otherwise }\end{array}$ \\
\hline SAFETY & $\begin{array}{l}1 \text { if one consider safety as an important attribute in selecting a } \\
\text { food product; } 0 \text { otherwise }\end{array}$ \\
\hline FEMALE & 1 if female; 0 if male. \\
\hline MARRIED & 1 if married; 0 otherwise \\
\hline EDU & 1 if one achieves a bachelor's degree or more; 0 otherwise. \\
\hline JOINT & 1 if the respondent live in a joint family; 0 otherwise \\
\hline CHILD & 1 if one is living with children of age 17 or younger; 0 otherwise \\
\hline INC1 & $\begin{array}{l}1 \text { if the annual income is between Rs } 50,000 \text { to }<100,000 ; 0 \\
\text { otherwise }\end{array}$ \\
\hline INC2 & $\begin{array}{l}1 \text { if the annual income is between Rs. } 100,000 \text { to }<250,000 ; 0 \\
\text { otherwise }\end{array}$ \\
\hline INC3 & 1 if the annual income is above 250,$000 ; 0$ otherwise \\
\hline AGE & 1 if one's age is above 30; 0 otherwise 0 \\
\hline SURVEY & 1 if Ahmedabad city survey; 0 if internet survey \\
\hline NG & 1 if non-GM is chosen initially; 0 otherwise. \\
\hline GM & 1 if GM is chosen initially; 0 otherwise. \\
\hline
\end{tabular}

For all three equations, price variable is quite significant. As the price variable represents difference between the price of non-GM and GM alternatives, the negative significant coefficient of this variable makes an intuitive sense. The higher the price difference the lower is the likelihood of acceptance of non-GM food, i.e., the more expensive the nonGM food (or less expensive the GM food) consumers are less likely to purchase non-GM food. The positive and significant coefficients of the HR and ETHIC variables indicate that perception of health risks and ethical considerations increase the acceptance of nonGM foods. However, ethical consideration seems unimportant in the case of choice between GM fed chicken and non-GM fed chicken. For all three food products, if one considers government regulatory performance as excellent or good then this does not increase the possibility of choosing non-GM foods. One may argue that if regulatory 
mechanism for GM foods is (perceived to be) satisfactory by consumers, it may not go against consumers' decision to choose GM foods.

Table 4.10: Logit Regression Estimates for Rice, Edible Oil and Chicken

\begin{tabular}{|c|c|c|c|}
\hline \multirow{2}{*}{ Variable } & \multicolumn{3}{|c|}{ Initial and Follow-up Responses } \\
\hline & Rice & Oil & Chicken \\
\hline PRICE & $\begin{array}{c}-.340^{* *} \\
(.025)\end{array}$ & $\begin{array}{c}-0.126^{* *} \\
(.010)\end{array}$ & $\begin{array}{c}-0.053^{* *} \\
(0.10)\end{array}$ \\
\hline KNOW & $\begin{array}{l}-0.275 \\
(.204)\end{array}$ & $\begin{array}{c}.021 \\
(.200)\end{array}$ & $\begin{array}{c}-0.412 \\
(0.518)\end{array}$ \\
\hline HR & $\begin{array}{c}0.733^{* *} \\
(.197)\end{array}$ & $\begin{array}{l}.600 * * \\
(.205)\end{array}$ & $\begin{array}{l}1.145^{* *} \\
(0.418)\end{array}$ \\
\hline ETHIC & $\begin{array}{c}0.514 * * \\
(.133)\end{array}$ & $\begin{array}{l}.502 * * \\
(.130)\end{array}$ & $\begin{array}{c}0.259 \\
(0.278)\end{array}$ \\
\hline SAFETY & $\begin{array}{l}-0.154 \\
(.126)\end{array}$ & $\begin{array}{l}-.023 \\
(.124)\end{array}$ & $\begin{array}{c}0.049 \\
(0.260)\end{array}$ \\
\hline GOVT & $\begin{array}{l}0.136 \\
(.157)\end{array}$ & $\begin{array}{l}-.163 \\
(.155)\end{array}$ & $\begin{array}{c}-0.529 \\
(0.390)\end{array}$ \\
\hline FEMALE & $\begin{array}{c}0.428 * * \\
(.134)\end{array}$ & $\begin{array}{l}.460 * * \\
(.135)\end{array}$ & $\begin{array}{c}0.171 \\
(0.282)\end{array}$ \\
\hline MARRIED & $\begin{array}{l}-0.088 \\
(.236)\end{array}$ & $\begin{array}{l}-.225 \\
(.230)\end{array}$ & $\begin{array}{c}0.062 \\
(0.467)\end{array}$ \\
\hline EDU & $\begin{array}{l}-0.185 \\
(.153)\end{array}$ & $\begin{array}{l}-.055 \\
(.154)\end{array}$ & $\begin{array}{c}0.307 \\
(0.467)\end{array}$ \\
\hline JOINT & $\begin{array}{l}0.301^{*} \\
(.133)\end{array}$ & $\begin{array}{l}.567 * * \\
(.134)\end{array}$ & $\begin{array}{c}0.599 \\
(0.299)\end{array}$ \\
\hline CHILD & $\begin{array}{l}-0.081 \\
(.143)\end{array}$ & $\begin{array}{l}.186 \\
(.144)\end{array}$ & $\begin{array}{l}-0.206 \\
(0.303)\end{array}$ \\
\hline INC1 & $\begin{array}{c}-0.454 * * \\
(.157)\end{array}$ & $\begin{array}{c}-.640 * * \\
(.159)\end{array}$ & $\begin{array}{c}-1.128 * * \\
(0.335)\end{array}$ \\
\hline INC2 & $\begin{array}{c}-0.663 * * \\
(.193)\end{array}$ & $\begin{array}{c}-1.180^{* *} \\
(.199)\end{array}$ & $\begin{array}{c}-1.672^{* *} \\
(0.467)\end{array}$ \\
\hline INC3 & $\begin{array}{l}-0.215 \\
(.262)\end{array}$ & $\begin{array}{l}-.651^{*} \\
(.274)\end{array}$ & $\begin{array}{c}-0.714 \\
(0.520)\end{array}$ \\
\hline AGE & $\begin{array}{c}-0.853 * * \\
(.288)\end{array}$ & $\begin{array}{c}-.793 * * \\
(.300)\end{array}$ & $\begin{array}{c}0.027 \\
(0.930)\end{array}$ \\
\hline SURVEY & $\begin{array}{l}0.282^{*} \\
(.147)\end{array}$ & $\begin{array}{l}.241 \\
(.143)\end{array}$ & $\begin{array}{l}-0.158 \\
(0.787)\end{array}$ \\
\hline $\mathrm{NG}$ & $\begin{array}{c}3.849 * * \\
(.395)\end{array}$ & $\begin{array}{c}2.230 * * \\
(.395)\end{array}$ & $\begin{array}{c}3.141 * * \\
(0.537)\end{array}$ \\
\hline GM & $\begin{array}{c}-2.911 * * \\
(.384)\end{array}$ & $\begin{array}{c}-4.301 * * \\
(.399\end{array}$ & $\begin{array}{c}-2.547^{* *} \\
(0.584)\end{array}$ \\
\hline CONSTANT & $\begin{array}{l}0.024 \\
(.453)\end{array}$ & $\begin{array}{c}1.648^{* *} \\
(.437)\end{array}$ & $\begin{array}{c}0.784 \\
(0.723)\end{array}$ \\
\hline-2 log- likelihood & 1929.70 & 1926.99 & 472.90 \\
\hline Cox \& Snell $\mathrm{R}^{2}$ & 0.476 & 0.485 & 0.449 \\
\hline $\mathrm{N}$ & 2937 & 2834 & 600 \\
\hline
\end{tabular}

* significant at $5 \%,{ }^{* *}$ significant at $1 \%$. Figures in parenthesis are standard errors. 
The coefficients on income levels are negative. The coefficients are statistically very significant as one moves away from the very poor income bracket to middle income brackets. However, as one moves to high income bracket this is not so. This implies that the lower middle class and middle class sections of the society are more likely to consume GM foods. Similarly, being female and joint family member increase the likelihood of choosing non-GM rice and edible oil. Education does not seem to affect the choice between the two food variants.

Based on the estimated logit equation, we also calculated mean willingness to pay for GM/non-GM foods. The expected willingness to pay is computed for each observation for each product and then the sample mean (expected premiums) is calculated. The premiums are presented both in Indian rupees and in percentages with regard to the relevant base prices of the three food products (Table 4.11). The results revealed that the mean WTP for non-GM rice, non-GM edible oil, and non-GM-fed chicken were Rs. 3.90, Rs. -8.06 , and Rs. 0.58 respectively. The negative signs for rice and edible oil indicate that on an average the consumers are willing to pay a premium for GM food, i.e., in percentage terms it implies that consumers do not mind paying $19.5 \%$ and $16.12 \%$ extra for GM rice and GM edible oil. This could be ascribed to a net benefit perceived due to high nutritive content and low pesticide usage for GM foods. In the case of chicken, however, on balance consumers seem to pay a very negligible premium for nonGM fed chicken.

Table 4.11: Mean Willingness to Pay for non-GM Foods

\begin{tabular}{|l|c|c|c|}
\hline Particulars & \multicolumn{3}{|c|}{ Mean of Initial and Follow-up Response } \\
\hline Base Price/kg & Rice (Rs. 20) & Oil (Rs. 50) & Chicken (Rs. 100) \\
\hline & \multicolumn{3}{|c|}{ All Respondents } \\
\hline Mean(Rs) & -3.90 & -8.06 & 0.58 \\
\hline Percentage & -19.5 & -16.12 & 0.58 \\
\hline & \multicolumn{3}{|c|}{ Non-GM Respondents } \\
\hline Mean(Rs) & 8.12 & 21.32 & 5.00 \\
\hline Percentage & 41 & 43 & 5.00 \\
\hline & -3.71 & -25 & -4.00 \\
\hline Mean(Rs) & -48 & -50 & -4.00 \\
\hline Percentage & \multicolumn{3}{|c|}{ Indifferent Respondents } \\
\hline & -0.994 & 7.36 & -0.809 \\
\hline Mean(Rs) & -4.97 & 14.72 & 0.008 \\
\hline Percentage & \multicolumn{3}{|c|}{} \\
\hline
\end{tabular}


The expected premiums at the sub-sample level are consistent. Those whose initial preference was for GM foods, are willing to pay a premium of Rs. 9.71 and Rs. 25.00 for GM rice and GM oil respectively. On the other hand, those whose initial preference was for non-GM foods are willing to pay a premium of Rs. 8.12 and Rs. 21.32 for non-GM rice and non-GM oil respectively. Thus, premium for GM foods is higher than the premium for non-GM foods at the sub-sample level. Moreover, in the sub samples, the expected premiums for non-GM fed chicken (Rs.5) is higher than the premium for GM fed chicken (Rs.4). Those who were indifferent between consuming GM rice and nonGM rice seemed to pay a premium of about Re.1 for GM rice. On the other hand, those who were indifferent between GM oil and non-GM oil were ready to pay a premium of about Rs. 7.30 for non-GM oil. Of course, the premiums for the indifferent households are very small, and, only about $2 \%$ of the sampled households were indifferent between the two types of rice and oil.

\section{Concluding Observations}

With rapid development of GM food crops in India and around the world, liberalized trade environment, stagnant productivity of green-revolution-era crops, and the burgeoning of population; policy makers in India will very soon be asking themselves How soon (and not If) they should allow production and import of GM food crops. In this context, while supply side issues have already been addressed to some extend, demand side issues were ignored altogether. Before GM foods get introduced in the Indian markets, it was imperative, therefore, that we know Indian consumers' level of understanding, perceptions, acceptability and willingness to pay for GM foods. We attempted just that. A random utility approach was used to estimate logit equations which indicate what factors affect the likelihood of consumption of non-GM and GM foods and whether or not consumers are willing to pay a premium for non-GM/GM foods. Data was generated through a questionnaire survey which was administered to 602 respondents in the city of Ahmedabad and 110 respondents on internet.

It turned out that awareness about GM technology was extremely low among the Ahmedabad city respondents who in our understanding were a representative sample of India. On the other hand, the internet savvy consumers were more aware of GM 
technology. However, after informing the city respondents about the pros and cons of GM foods, more than 70\% were willing to consume GM foods even if GM and non-GM foods were available for the same price. This indicates that information to consumers regarding the GM foods may have to be enhanced through consumer education societies, extension agencies of government ministries, and biotech food companies. In the absence of such information, one would be apprehensive about strong consumer reaction to sudden appearance of GM foods in Indian market.

It was also clear from the study that overwhelming proportion of Indian consumers would like to see mandatory labelling of GM foods, although about $30 \%$ of them did not want to pay for labelling. Regulatory authorities will have to consider this factor seriously, at least until such time that awareness and acceptability of GM foods is not pervasive. Results also suggest that if one considers government regulatory performance as excellent or good then this does not increase the likelihood of choosing non-GM foods. Internet based respondents were not much bothered about ethical and religious issues associated with GM foods, however, they were more averse to GM foods due to the perceived health risks associated with GM foods. On the other hand, although respondents from the city survey were concerned about ethical and religious issues, more than $70 \%$ of them were ready to consume GM foods. In fact, the lower middle class and middle class sections of the society are more likely to consume GM foods as compared to very poor and the high income consumers.

Regression results also suggest that controlling for other factors, likelihood of consumers opting GM food goes up if prices of GM foods go down or prices of non-GM foods go up. Thus, GM foods may become acceptable to Indian consumers for the right price. In fact, the mean WTP estimates suggest that consumers are, on an average, ready to pay $19.5 \%$ and $16.12 \%$ premiums for golden rice and GM edible oil, respectively. This could be ascribed to a net benefit perceived due to high nutritive content and low pesticide usage for GM foods. In the case of chicken, the overall premium for non-GM fed chicken was very negligible indicating that consumers are almost indifferent between GM fed chicken and non-GM fed chicken. This study was conducted in Ahmedabad, which in our opinion, is a representative cohort of Indian population in terms of mix of dwellers from rural town and a metropolitan city. Therefore, the study indicates that on the whole, 
GM foods may be acceptable in the Indian market provided information about GM technology and GM foods is passed-on to consumers in a planned manner.

\section{References}

Gupta, A. and V. Chandak (2005). "Agricultural Biotechnology in India: Ethics, Business and Politics," International Journal of Biotechnology, Vol. 7

ISAAA(2007). "ISAAA Brief 35-2006: Executive Summary," International Service for the Acquisition of Agri-biotech Applications, http://www.isaaa.org/resources/ publications/briefs/35/executivesummary/default.html, accessed on 14-7-07.

Kaneko, N. and W. Chern (2005). "Willingness to Pay for Genetically Modified Oil, Cornflakes, and Salmon: Evidence from a U.S. Telephone Survey," Journal of Agricultural and Applied Economics, Vol. 37, pp. 701-719.

Neilson, C. and K. Anderson (2000). "Global Market Effects of Adopting Transgenic Rice and Cotton," Mimeo, Centre for International Economic Studies, University of Adelaide, July.

Sommer, A. and K.P. West Jr (1996). Vitamin A Deficiency: Health, Survival and Vision, New York: Oxford University Press.

USDA (2005). "India Biotechnology Annual," GAIN Report Number IN5078, Foreign Agricultural Service, USDA.

Grainnet (2007). "India Eliminates Customs Duties on Corn Imports," accessed 15/7/07, http://www.grainnet.com/info/articles.html?ID=4120

Zhong. F., M.A. Marchant, Y. Ding, and K. Lu. (2002). "GM foods: A Nanjing case study of Chinese consumers' awareness and potential attitudes." AgBioForum, Vol.5, pp. 136-144. 